\title{
UN ALTAR VOTIV MINIATURAL DIN AȘEZAREA ROMANĂ DE LA OSTROV (PUNCTUL FERMA 4), JUD. CONSTANȚA
}

\author{
ADELA BÂLTÂC, IOANA PARASCHIV-GRIGORE
}

\section{A MINLATURE VOTIVE ALTAR FROM THE ROMAN SETTLEMENT OF OSTROV (PUNCTUL FERMA 4), CONSTANTA COUNTY}

The article presents a miniature votive altar found in the area of the Roman settlement, investigated by scheduled excavations since the early ' 90 s of the last century at Ostrov (Ferma 4). The altar is dedicated to Iupiter Optimus Maximus by Iulius Ponticus, most probably a veteran of Legio XI Claudia, quartered at Durostorum. The name indicates that the veteran might have been recruited from Pontus, thus having a PontoBythinian origin. Althought for the Durostorum area is known another individual character with the same cognomen (L. Numerius Ponticus), no connection can be established between the two persons. Also, there is included a review of the epigraphic finds in the area of ancient Durostorum and the information provided by these sources in regard to onomastic and religious elements.

KEYWORDS: Durostorum, inscriptions, veteran, Ponto-Bythinian CUVINTE CHEIE: Durostorum, inscripții, veteran, pontobithynian

Situl arheologic de la Ostrov (Punctul ferma 4, jud. Constanța) a fost, este și va fi mereu legat de anticul Durostorum'. Situl se află la o distanță de cca $4 \mathrm{~km}$ est de castrul legiunii XI Claudia, într-o zonă în care, după cel de-al doilea război mondial şi până în zilele noastre, se practică cultivarea viţei de $v^{2}{ }^{2}$, ceea ce a dus la deteriorarea permanentă a vestigiilor de aici. Indiferent de statutul ${ }^{3}$ aşezării, cercetate sistematic de la începutul anilor ' 90 ai secolului trecut, situl continuă să ofere un bogat material arheologic, care pune în valoare un habitat de proporții considerabile ${ }^{4}$. Pânã în prezent, investigațiile arheologice au pus în valoare 19 cuptoare de ars material din lut $^{5}$ (ceramic sau de construcție), cca 80 de gropi menajere ${ }^{6}$, toate reperate pe malul Dunării, dar şi trei clădiri de dimensiuni impozante ${ }^{7}$, cercetate sistematic din anul 1997. Totuşi, cercetările sunt departe de a fi finalizate, aducând an de an noi și noi date despre amploarea vieții din așezarea romană de aici.

\footnotetext{
' Despre anticul Durostorum, vezi Pârvan 1924; Gerov 1977; Doruţiu-Boilã 1978, 246-247; Culicã 1978; Muşețeanu 1990; Ivanov, Atanasov, Donevski 2006; Cîrjan 2010, 86-88; Aparaschivei 2010, 96-105, 195-197; Boyanov 2010a; Boyanov 2010b; Bâltâc 2011, 92-94

2 În perioada 1996-2005, zona a fost destelenită în vederea înnoirii culturii viței, fapt ce a condus la iniţierea cercetării de teren în așezarea propriu-zisă. Ulterior, proprietarul a replantat, lăsând o suprafață de cca 5 ha unde se desfaşoară cercetările arheologice sistematice.

${ }^{3}$ Controversele legate de anticul Durostorum decurg din realităţile oferite de sursele epigrafice, care atestă existenţa unor canabae ce poartă gentiliciul imperial de Aeliae (CIL III, 7474), statutul de municipium acordat aşezării (Pârvan 1924, 318 ; ISM I, 302) și un vicus populat de veterani consistentes (Gerov 1977, 302-304; Banev 2001, 34) documentat ulterior atestării statutului de municipium. Astfel, printre cercetători s-au formulat două opinii, una conform căreia aşezarea care se municipalizează sunt acele canabae ale legiunii (Pârvan 1924, 318; Gerov 1977, 299-300; Boyanov 2010a, Boyanov 2010b), identificate în apropierea castrului legiunii (Donevski 1990, 238-239 şi fig. 1; Ivanov, Atanasov, Donevski 2006, 166-180) și alta, conform căreia aşezarea civilă de tip vicus primește statutul de municipium (Doruţiu-Boilă 1978, 246-247; Donevski 1990, 243; Cîrjan 2011,74), aşezare identificată cu structurile cercetate în punctul „Ostrov ferma 4”.

${ }^{4}$ Cercetările perieghetice efectuate de-a lungul timpului, inclusiv observații recente, făcute în timpul lucrărilor de aducţiune a apei în via dimprejur, precum şi mormintele semnalate prin cercetări de salvare sau periegheze pe malul Dunării, indică o suprafaţă a habitatului de cca 24 ha, ceea ce poate aduce argumente în favoarea ipotezei conform căreia aici se află o aşezare de dimensiuni apreciabile.

${ }^{5}$ Mușețeanu 2003

${ }^{6}$ Informaţie Dan Elefterescu (căruia îi mulţumim). Până acum a fost publicat materialul provenind din 11 gropi şi un cuptor, vezi Mușețeanu 2003; Mușețeanu, Elefterescu 2004.

${ }^{7}$ Damian, Bâltâc 2008 cu completările din rapoartele anuale CCA 2008, 212-214; CCA 2009, 159-160; CCA 2010, 132-136; CCA 2011, 93-94; CCA 2012, 93-94; CCA 2013, 96-97.
} 
În primăvara anului 2012 , cu ocazia unor lucrări agricole specifice ${ }^{8}$, a fost descoperit un altar votiv miniatural $^{9}$ (PI. I), într-o zonă situată aproximativ la 75-80 m vest de edificiul termal ${ }^{10}$.

Altarul (nr. inv. MNIR 341.695) are formă paralelipipedică şi este de mici dimensiuni, având o înălțime de $19,50 \mathrm{~cm}$, lățimea la partea superioară de $11,60 \mathrm{~cm}$, iar în partea inferioară de $11 \mathrm{~cm}$. Grosimea variază între 10 și $10,50 \mathrm{~cm}$. Altarul este confecționat din calcarenit ${ }^{\prime \prime}$ şi se păstrează într-o stare relativ bună, prezentând doar ciobituri, spărturi şi incizii recente (pe spate şi pe părțile laterale, $\mathbf{P l}$. I/2-3), cel mai probabil datorate lamei unui utilaj agricol. De asemenea, prezintă o spărtură, din vechime, în colțul din dreapta sus al piesei. Cu toate acestea, se poate observa că marginea superioară a altarului era decorată; se păstrează doar voluta din stânga, redată destul de stângaci, ceea ce poate indica un decor în formă de capitel. Bordura inferioară este doar uşor profilată. Pe întreaga suprafață a inscripției se observă urme de vopsea de culoare roșie.

Literele sunt incizate relativ neglijent, neuniform, cu stângăcie, rândurile fiind înclinate spre stânga jos, şi au înălțimi variate (pe fiecare rând): rândul $1: 34-38 \mathrm{~mm}$, rândul $2: 28-47 \mathrm{~mm}$, rândul 3: 22-25 mm, rândul 4: 15-22 mm; adâncimea literelor este între 1 și $3 \mathrm{~mm}$. Distanța dintre rânduri variază între $0,80-1,80 \mathrm{~cm}$.

Textul inscripției:

\section{I(ovi) O(ptimo) M(aximo) \\ IVL(ius) \\ PONTIC(us) \\ VET(eranus)}

r.1. Cele două haste interioare ale litere $M$ se intersectează şi se suprapun. Între fiecare literă câte un ,punct”.

r.2. Hasta orizontală a literei L este mult aplecată în jos (oblică). La sfârșitul rândului un ,punct".

r.3. Sub litera P sunt incizate două linii, intersectate (formează simbolul „, cel mai probabil un accident în piatră la scriere). Litera $\mathrm{N}$ are hasta din stânga mai alungită, iar celelalte sunt suprapuse. Hasta orizontală a literei $T$ este redată vălurit. Litera $I$ are hasta orizontală redată vălurit, iar partea inferioară a hastei verticale se prelungeşte spre stânga, astfel încât se poate spune că este redată şi litera $\mathrm{C}$, în ligatură. La sfârşitul rândului un ,punct”. În zona literelor P şi $\mathrm{O}$ mici ciobituri în suprafața pietrei.

r.4. Vârful literei $V$ este foarte ascuțit, în formă de vârf de săgeată. La sfầrşitul rândului, un „punct”. În zona hastei mediane a literei E şi sub litera T mici ciobituri pe suprafaţa pietrei.

Se observă diferențe între redarea literelor $\mathrm{I}, \mathrm{V}$ și $\mathrm{T}$, de la un rând la altul.

Datare propusă: sfârşitul secolului al II-lea-începutul secolului al III-lea.

Materialele epigrafice din zona anticului Durostorum nu sunt foarte numeroase și nu au fost cuprinse într-un corpus specific ${ }^{12}$. În general, despre piesele mai vechi (de la sfârșitul secolului al XIX-lea și începutul secolului XX), inclusiv cele care fac referire la elemente legate de administrație, viața religioasă, civilă sau citadină, se cunosc puține informații legate de condițiile de descoperire, referirile fiind neclare sau ambigue asupra locului de proveniență. Unele provin din perimetrul

\footnotetext{
${ }^{8}$ Piesa a fost recuperată și predată colectivului şantierului de către doamna inginer Zenaida Cazacu, căreia îi mulțumim și aici.

9 Mulţumim dr. Paul Damian, responsabil ştiințific al şantierului de la Ostrov, pentru punerea la dispoziţie, spre publicare, a acestei inscripţii.

${ }^{10}$ Este vorba despre un edificiu, orientat SSE-NNV, cu o suprafą̧ă estimată de $500 \mathrm{~m}^{2}$, compartimentat în mai multe spații, dintre care trei prevăzute cu instalaţie de hypocaust, mai multe bazine şi o palaestra? pe latura de vest. Edificiul cunoaşte trei faze de funcționare, începând cu secolul al II-lea, până la începutul celui de-al IV-lea p. Chr. Vezi supra nota 7.

${ }^{11}$ Calcarenit de culoare crem, fin cochilifer $(\sim 1 \mathrm{~mm})$, foarte omogen, compact; analiză realizată de dr. Constantin Haită, căruia îi mulţumim.

${ }^{12}$ Acestea sunt în jur de 43: CIL III, nr. 6152 (=7478), 7474, 7475, 7476, 7477, 7480, 12456, 12457, 12458, 12459, 12460, 14213,3; Kalinka 1906, nr. 220, 226, 375, 380, 411, 417, 418, 426; Pârvan 1924, p. 310, 317, 318; Russu 1933-1935, nr. 1-6; IGB II, 865 (=IGB V, 5389), 866; Donevski 1976, nr. 1-5; Georgiev 1974, $96-97$ (= Gerov 1977, 302-304 = Banev 2001, 34); Bărbulescu-Munteanu, Rădulescu 1982, 155; Petolescu 2004, 239; AÉ 2004, nr. 1269; AÉ 2009, 1203; Boyanov 2010a, 53 (=Boyanov 2010b, 295). Aici se pot adăuga două altare de la Călărași (inedite, vezi infra) şi alte patru inscripţii, în curs de publicare, de către colegul bulgar Ilian Boyanov (căruia îi mulțumim pentru informaţie).
} 
orașului Silistra, altele din apele Dunării ${ }^{13}$, pe când unora (inclusiv mult discutata inscripție cu canabae Aeliae $^{14}$ ) le sunt date ca locuri de descoperire zone din apropierea oraşului Silistra ${ }^{15}$, poate chiar din locul unde astăzi se desfășoară cercetările arheologice din punctul ferma 4. Și piesele mai recente, descoperite cu ocazia cercetărilor arheologice din Silistra, provin din poziții secundare, fiind refolosite ca materiale de construcție la diverse complexe ${ }^{16}$ databile în epocile romano-bizantină sau chiar medievală ${ }^{17}$. Din păcate, până acum, nicio piesă epigrafică din zona anticului Durostorum nu este descoperită într-o poziție stratigrafică certă.

Nici zona cercetată sistematic în punctul Ostrov ferma 4 nu face excepție. Până în acest moment, în zona aşezării au fost găsite șase altare miniaturale ${ }^{18}$, însă acestea sunt tot descoperiri fortuite. Autorul acestor descoperiri, Dan Elefterescu, menționează că acestea au fost recuperate în timpul perieghezelor efectuate de-a lungul mai multor ani pe malul Dunării, într-o zonă situată aproximativ la $50 \mathrm{~m}$ est de locul în care a fost semnalat și cercetat Cuptorul nr. $19^{19}$. Această zonă se află pe malul Dunării, la cca 200 m vest de edificiul termal. Dat fiind faptul că în anii mai secetoşi, pe malul Dunării, în zona așezării, se pot observa mai multe obiecte din piatră, care însă pot proveni și din amonte, este greu de precizat dacă cele șase altare s-au prăbușit din același loc, eventual din același complex.

Așa cum am menționat, nici altarul care face obiectul articolului de față nu provine dintr-o poziție stratigrafică certă, însă este prima piesă epigrafică care este sigur descoperită în zona așezării romane şi nu putem să nu facem legătura și cu altarele descoperite pe malul Dunării, aflate, după cum se poate vedea, în zone apropiate.

În ceea ce privește altarul de față, nu sunt foarte multe aspecte de evidențiat. Acesta este dedicat zeului Iupiter de către un veteran ${ }^{20}$, cel mai probabil al legiunii XI Claudia. Dedicațiile către Iupiter Optimus Maximus, sunt printre cele mai frecvente între dedicațiile din zona anticului Durostorum ${ }^{21}$.

În ceea ce-l privește pe veteranul Iulius Ponticus, este de presupus că va fi fost locuitor în așezarea de aici. Din zona Durostorum mai este cunoscut un personaj care poartă cognomenul de Ponticus $^{22}$ și anume L. Numerius Ponticus, duumvir al municipiului, atestat cândva între anii 169-176 p. Chr., însă este foarte greu să se stabilească o legătură între acesta și veteranul Iulius Ponticus. De asemenea, numele de Iulius este des întâlnit în zona Durostorum, fiind cunoscute mai multe personaje, chiar veterani, care poartă acest nume ${ }^{23}$. Dat fiind faptul cã Iulius Ponticus este, foarte probabil, un veteran al legiunii XI Claudia, el nu poate fi identificat cu alte două personaje care poartă același nume, cunoscute din două inscripții de la Troesmis ${ }^{24}$.

${ }^{13}$ Pentru cele mai multe dintre piesele publicate în CIL sau AÉ și cele publicate de Ernst Kalinka se dau ca repere: oraşul Silistra (eventual unele case particulare sau cimitirul), ruinele fortăreței medievale, apele Dunării, colecţia fostului Liceu de Băieți din Silistra. Cele editate de I.I. Russu provin din aşa numita „colecţia Papahagi” (pentru aceastā colecție, vezi Știrbulescu 2007, 284-285).

14 "... gefunden auf dem $r$. Donauufer, ca. 4 Kilometer weit von Silistria in der Richtung gegen Ostrov in der Schanze cines rö̈... Lagers." Grigore Tocilescu (AEM, VI, 3, nr. 1); „... a quattro chilometri da Silistra verso Ostrov" (Pârvan 1924, 333).

${ }^{15}$ Pârvan 1924, 318; Bărbulescu-Munteanu, Rădulescu 1982, 155.

${ }^{16}$ Georgiev 1974, 95 - în construcția unui pod antic; Donevski 1976, 61 - la clădiri din secolul al IV-lea.

${ }^{17}$ Boyanov 2010b, 295 - ca prag, într-o construcție din secolul al XIV-lea. Este vorba despre cea mai recentã inscripție care a redeschide dezbaterea asupra momentului obținerii statutului de municipiu şi a structurii care a obținut acest statut. Altarul ar fi putut fi adus de oriunde din împrejurimile anticului Durostorum, inclusiv de la Ostrov, punctul ferma 4, unde este localizat unul dintre toponimele (Gavidina) care apar în inscripție (Boyanov 2010a, 57).

${ }^{18}$ Acestea se află în patrimoniul Muzeului Dunării de Jos, Călăraşi. Din menţiunile lui Dan Elefterescu, doar două prezintă inscripții, restul fiind anepigrafice.

${ }^{19}$ Muşețeanu, Elefterescu 2004, 128 , pl. 1.

${ }^{20} \mathrm{De}$ altfel, cele mai multe dedicații din zona Durostorum aparțin veteranilor (8) şi militarilor (6).

${ }^{21}$ Dintre inscripțiile închinate unor divinități, şapte sunt către Iupiter, două dintre acestea în asociație cu Iunona (CIL III, 7474, 14213,3; Pârvan 1924, 317, 318; Donevski 1976, nr. 1-2; Boyanov 2010a, 53), două către zeul Mithras (CIL III, 7475, Russu 1933-1935, nr. 3), una către Mercur (Georgiev 1974, 97), una cātre Plutos (Russu 1933-1935, nr. 2), una către Heros - cu epitetul Surgethia- (Pârvan 1924, 310) și opt către zeii subpământeni (CIL III, 6126, 6152, 7477, 7479, 14213/2, 14434; Bărbulescu-Munteanu, Rădulescu 1982, 155; Petolescu 2004, 239).

${ }^{22}$ Pârvan 1924, 318; Aparaschivei 2010, 195.

${ }^{23}$ Din cele 70 de nume atestate în inscripțiile din zona Durostorum (vezi supra nota 12), cel mai des întâlnit este numele Valerius/Valeria (17), urmātorul fiind Iulius (7), apoi Aurelius/Aurelia (4); alte nume apar în mențiuni singulare sau de două/trei ori (vezi şi anexa 1).

24 ISM V, 137 și 186. Cele douã inscripții atestã de fapt trei personaje cu același nume, însã unul dintre ei decedează încă din timpul serviciului militar. Pentru o analiză asupra acestor personaje, vezi şi Mihăilescu-Bîrliba 2008-2009. 
Numele de Iulius este des întâlnit în provincia Moesia Inferior ${ }^{25}$, ca de altfel în întreg Imperiul ${ }^{26}$, însă cognomenul de Ponticus este mai puțin întâlnit, atât în provincie ${ }^{27}$, cât și în Imperiu ${ }^{28}$. Acest cognomen este considerat a fi o caracteristică a locului de origine a personajului care-l poartă ${ }^{29}$. Astfel, este de presupus că şi personajul de față putea fi la origini din Pontus ${ }^{30}$, de unde a fost recrutat pentru a servi în legiunea de la Durostorum, unde se va stabili ulterior. Pe lângă cele două personaje de origine pontobithyniană, mai sus menționate, din zona Durostorum mai sunt cunoscute alte două personaje cu origini orientale ${ }^{31}$, ambii făcând dedicații către zeul Mithras. Dacă la aceste două dedicații adăugăm și alte reliefuri votive dedicate acestui zeu, se poate vorbi despre existența unei comunități orientale în zona Durostorum. Deși analiza inscripțiilor a relevat faptul că onomastica latină predomină în această zonă, nu toate personajele au o origine romană, aşa cum indică, spre exemplu, piatra funerară a lui Valerius Marcus $^{32}$ (ai cărui urmași trădează originile tracice ale familiei) sau numeroasele nume de origine grecească atestate de inscripții (anexa 1). Astfel, și în zona anticului Durostorum se poate vorbi despre un bogat mozaic etnic și religios.

Aşa cum arată această scurtă analiză efectuată de noi, cu toate că nu sunt foarte numeroase, inscripțiile din zona Durostorum, pot oferi o varietate de informații privind aspecte cum ar fi organizarea administrativă, structura socială, complexitatea vieții civile și militare.

\section{BIBLIOGRAFIE}

Aparaschivei 2010

Banev 2001

Bărbulescu-Munteanu, Rădulescu 1982

Bâltâc 2011

Boyanov 2010a

Boyanov 2010b

CCET II/1

Cîrjan 2010

Cîrjan 2011

Culică 1978
D. Aparaschivei, Oraşele romane de la Dunărea Inferioară (secolele I-III p. Chr.), Iași, 2010

K. Banev, Addenda et corrigenda epigraphica (II), Archaeologia Bulgarica, V, 2001,2 , p. 31-35

Maria Bărbulescu-Munteanu, A. Rădulescu, Colonia Ulpia Zamizegetusa pe o inscriptie din Dobrogea, Pontica, XV, 1982, p. 153-159

A. Bâltâc, Lumea rurală în provinciile Moesia Inferior şi Thracia (secolele I-III p. Chr.), București, 2011

I. Boyanov, Municipium Aurelium Durostorum or vicus Gavidina, Archaeologica Bulgarica, XIV, 2 (2010), p. 53-59

I. Boyanov, Нови данни за развитието на Дуросторум през Принципата, în Studia Archaeologica Universitatis Serdicensis, Supplementum V (2101), Archaeologicos in honorem Professoris Stephcae Angelova, p. 295-301

Zl. Gočeva, M. Oppermann, Corpus Cultus Equitis Thracii, II. Monumenta inter Danubium et Haemum reperta, fas. 1. Durostorum et vicinia, regio oppidi Tolbuhin, Marcianopolis et vicinia, regio opipidi Šumen, Leiden, 1981

R. Cîrjan, Statute citadine privilegiate în provinciile Dunărene ale Imperiului Roman, Cluj-Napoca, 2010

R. Cîrjan, Nouvell estémoignages sur les canabae de la Xle légion Claudia à Durostorum, $M C A$ (serie nouā), VII, 2011, p. 73-81

V. Culică, Cu privire la lagărul legiunii a XI-a Claudia la Dunărea de Jos, Pontica, XI, 1978, p. 113-119

\footnotetext{
${ }_{25}$ Pentru Dobrogea, vezi ISM I, II, III, V (indicii), pentru Bulgaria, Minkova 2000, 57-61.

${ }^{26}$ Onomasticon II, 200-207

${ }^{27}$ Sub forma latinească Ponticus se cunosc cinci personaje de la Troesmis (ISM V, 137, 186), unul de la Durostorum (Pârvan 1924,318 ) şi unul de la Cumpāna (ISM II, 129), sub forma grecească Pón t i ko̧ la Histria (ISM I, 100), la Tomis (ISM II, 13, 31, 83). În unele situaţii el apare ca nomen (Histria - ISM I, 197, 212; Tomis - ISM II, 83, 125, 279, 293, 468). Este posibil să mai fie și alte personaje în provincie, dat fiind faptul că inscripțiile latine din Bulgaria şi din sudul Dobrogei nu sunt adunate în corpora specifice, statistica de mai sus a fost realizată doar pe baza informațiilor existente în AÉ, CIL, IGB,

ILB, ISM şi Montana, 2, nu şi în alte publicaţii.

${ }^{28}$ Onomasticon III, 152-153

${ }^{29}$ Pape, Bensler 1911, 1233-1234

${ }^{30}$ Despre o analiză a origini orientalilor din Moesia Inferior pe baze onomastice, vezi Curcă, Zugravu 2005.

${ }^{31}$ Q. Samicius Serenus (Russu 1935, nr. 3) şi Comelius Faustus (CIL 03, 07475).

${ }^{32}$ CIL III, 7477
} 
Curcă, Zugravu

Damian, Bâltâc 2008

Donevski 1976

Donevski 1990

Doruţiu-Boilă 1978

Georgiev 1974

Gerov 1977

IGB II

Ivanov, Atanasov, Donevski 2006

Kalinka 1906

Mihăilescu-Bîrliba

Minkova 2000

Montana II

Mușețeanu 1990

Mușețeanu 2003

Mușețeanu,

Elefterescu 2004

Onomasticon

Pape, Bensler 1911

Pârvan 1924

Petolescu

Russu 1933-1935

Ştirbulescu 2007
R. Curcă, N. Zugravu, Orientaux dans la Dobroudja romaine. Une approche onomastique, în V. Cojocaru (ed.), Ethnic Contacts and Cultural Exchange North and West of the Black Sea Coast from the Greek Colonization to the Ottoman Empire, Iasi, p. 313-329

P. Damian, A. Bâltâc, The Civil Roman Settlement at Ostrov-Durostorum, în Acts of the International Colloquium Important Sites from the Pre-Roman and Roman Time on the Lower Danube Valley ( $4^{\text {th }}$ century BC- $4^{\text {th }}$ century AD), Istros 14,2008 , p. $61-70$

П.. Доневскии, Латински надписи от Дуросторум, Arheologja, 1976, 4, p. 61-64

P. Donevski, Zur Topographie von Durostorum, Germania, 68, 1990, 1, p. 236-245

Emilia Doruţiu-Boilă, Über den Zeitpunkt der Verleihung des Munizipalrechts in Scythia Minor, Dacia N.S., XXII, 1978, p. 245-247

П. Георгиев, Римски статуи и надписи от Силистра, Известия на Народния Музей Варна, p. 95-102

B. Gerov, Zum Problem der Entstehung der römischen Städte am Unteren Donaulimes, Klio, 59, 2, 1977, p. 299-309

G. Mihailov, Inscriptiones Graecae in Bulgaria repertae. Volumen II. Inscriptiones inter Danubium et Haemumrepertae, Serdicae, 1958

Р. Иванов, Г. Атанасов, П. Доневси, Историяна Силистра, том. 1 Античният Дуросторум, София (History of Silistra, I, The ancient Durostorum, Sofia, 2006

E. Kalinka, Antike Denkmäler in Bulgarien, Wien, 1906

L. Mihăilescu-Bîrliba, Două familii de pontobitynieni la Troesmis, Analele Stiintifice ale Universității "Alexandru Ioan Cuza”, din Iași, S.N. Istorie, LIV-LV, 2008-2009, p. 17-23

M. Minkova, The Personal Name of the Inscriptions in Bulgaria (Studien zur klassischen Philologie 118), Frankfurt am Main-Berlin-Bern-Bruxelles-New York-Wiena, 2000

В. Велков, Г. Александров, Монтана, 2, Епиграфски паметнищи от Монтана и района, Монтана [Montana], 1994

Cr. Muşeţeanu, Contribuţii privind topografia Durostorului, $S C I V A, 41,1990,3-4$, p. 293-299

Cr. Muşețeanu, Ateliere ceramice romane de la Durostorum, Bucureşti, 2003

Cr. Mușețeanu, D. Elefterescu, Contribuţii privind ceramica romană de la Durostorum (IV), Peuce. SN, II (XV), 2004, p. 95-142

Onomasticon Provinciarum Europae Latinarum, II. Viena, 1999; III. Viena, 2000

W. Pape, G. Bensler, Wörterbuch der griechischen Eigennamen, I-II, Braunschweig, 1911

V. Pârvan, Municipium Aurelium Durostorum, Rivista di Filologia e d'Istruzione Classica, II, 1924, 3, p. 307-340

C-tin. C Petolescu, O inscripție din patrimoniul Muzeului din Călăraşi, în I. Cândea, V. Sârbu, M. Neagu (ed.), Prinos lu Petre Diaconu la 80 de ani, p. 237-246

I.I. Russu, Inscriptii latine din Durostorum, Anuarul Institutului de Studii Clasice, Cluj, II, 1933-1935, p. 201-218.

Ch. Ştirbulescu, Un sarcofag descoperit în com. Ostrov, jud. Constanța, Pontica, XL, 2007, p. 283-306

LIST OF ILLUSTRATION

PI. I. The miniature votive altar from Ostrov (Point Ferma 4, Constanța county) - photo George Nica

ADELA BÂLTÂC, IOANA PARASCHIV-GRIGORE

Muzeul Naţional de Istorie a României,

Secției de Arheologie Pre- şi Protoistorică, Clasică şi Medievală adelabaltac.mnir@gmail.com; ioangri@gmail.com 
ANEXA 1

\begin{tabular}{|c|c|c|c|c|}
\hline & $\begin{array}{l}\text { NUME PERSONAJE DIN } \\
\text { INSCRIPTII }\end{array}$ & $\begin{array}{c}\text { FUNCTII/OCUPATII/ALTE } \\
\text { ELEMENTE }\end{array}$ & $\begin{array}{l}\text { DATARE } \\
\text { (P. CHR.) }\end{array}$ & SURSA \\
\hline 1. & Caius Antonius Herculanus & veteran (LEG XI CLAUDIA) & \multirow{18}{*}{209} & \multirow{18}{*}{$\begin{array}{l}\text { Gerov 1977, 302-303; } \\
\text { Banev 2001, } 34\end{array}$} \\
\hline 2. & Valerius Villanus & preot & & \\
\hline 3. & Publicius Priscus & veteran? & & \\
\hline 4. & Iulius Crispinus & veteran & & \\
\hline 5. & Iulius Iulianus. & veteran & & \\
\hline 6. & Aurelius Asclas & veteran & & \\
\hline 7. & Cocceius Herculanus & veteran & & \\
\hline 8. & Valerius Valerianus & veteran & & \\
\hline 9. & Comelius Lucius & veteran & & \\
\hline 10. & (A)elius? Aelianus & veteran & & \\
\hline 11. & Flavius Caius & - & & \\
\hline 12. & Flavius Valerius & - & & \\
\hline 13. & Valerius Quintus & - & & \\
\hline 14. & Valerius Apollinaris & - & & \\
\hline 15. & Cocceius Vale(ns)? & - & & \\
\hline 16. & Septimius? Sempronius & - & & \\
\hline 17. & Valerius Valentin $(. .)$. & - & & \\
\hline 18. & Valerius Pudi( $(.)$. & - & & \\
\hline 19. & Cneius Oppius Soterichus & - & $139-161$ & CIL IIL 7474 \\
\hline 20. & Oppius Severus & - & $139-101$ & CIL III, $/ 4 / 4$ \\
\hline 21. & Caius Valerius Iulianus & militar (LEG XI CLAUDIA) & \multirow{7}{*}{$251-300$} & \multirow{7}{*}{$\begin{array}{l}\text { Bărbulescu, } \\
\text { Rădulescu 1982, } 155\end{array}$} \\
\hline 22. & Pompeia Aquilina & soția defunctului & & \\
\hline 23. & Valerius Aquilinus & fiul defunctului & & \\
\hline 24. & Pompeia Iuliane (sic!) & fiica defunctului & & \\
\hline 25. & Valerius Iulianus & fiul defunctului & & \\
\hline 26. & Valerius Vibianus & fiul defunctului & & \\
\hline 27. & Pompeius Iulianus & fiul defunctului & & \\
\hline 28. & Iulius Firmus & - & Sec. II-III & CCET II $/ 1,181$ \\
\hline 29. & Aurelius Maturus & militar (LEG XI CLAUDIA) & $201-300$ & Pârvan 1924,310 \\
\hline 30. & Caius Terentius Herodianus & duumvir & \multirow{6}{*}{$169-176$} & \multirow{6}{*}{ Pârvan 1924, 318} \\
\hline 31. & Lucius Numerius Ponticus & duumvir & & \\
\hline 32. & Titus Flavius Papirianus & aedilis & & \\
\hline 33. & Claudius Saturninus & aedilis & & \\
\hline 34. & Quintus Visellius Lollianus & quaestor & & \\
\hline 35. & Titus Lucretius Felix & quaestor & & \\
\hline 36. & Iulius Eutuches & libert(?) & \multirow{2}{*}{ Sec. II-III } & \multirow{2}{*}{ Boyanov 2010a } \\
\hline 37. & Iulius Maximu(s) & patronul precedentului & & \\
\hline 38. & Antonius Valerius & $\begin{array}{c}\text { militar (CLASSIS II FLAVIA } \\
\text { BRITANNICA) }\end{array}$ & Sec. II-III & $\begin{array}{c}\text { CIL III, } 6152=\text { CIL III, } \\
7478\end{array}$ \\
\hline 39. & Comelius Fau(s)tus & militar (LEG XI CLAUDIA) & Sec. II-III & CIL III, 7475 \\
\hline 40. & Quintus Carmaeus Laetus & militar (LEG XI CLAUDIA) & & \\
\hline 41. & Quintus Carmaeus Felix & -- & Sec. $11-111$ & CIL III, /4/6 \\
\hline 42. & Valerius Marcus & militar (LEG XI CLAUDIA) & \multirow{7}{*}{ Sec. II-III } & \multirow{7}{*}{ CIL III, 7477} \\
\hline 43. & Aurelia Faustina & soția defunctului & & \\
\hline 44. & Valerius Decibal M & fiul defunctului & & \\
\hline 45. & Valerius Seiciper & fiul defunctului & & \\
\hline 46. & Valerius Mamutzim & fiul defunctului & & \\
\hline 47. & Valeria Macaria & fiica defunctului & & \\
\hline 48. & Valeria Matidia & fiica defunctului & & \\
\hline 49. & Cat $(. .$.$) rus$ & vilicus & \multirow{2}{*}{$101-300$} & \multirow{2}{*}{$\begin{array}{c}\text { CIL III, } 7479=\text { CIL III, } \\
12454\end{array}$} \\
\hline 50. & Valeria Eirene & soția defunctului & & \\
\hline 51. & (Val)ens & militar (LEG XI CLAUDIA) & Sec. II-III & CIL III, 12458 \\
\hline
\end{tabular}




\begin{tabular}{|c|c|c|c|c|}
\hline 52. & Aelia Avilia & - & \multirow{2}{*}{$101-300$} & \multirow{2}{*}{ Kalinka 1906, 375} \\
\hline 53. & Iulius Iulianus & militar & & \\
\hline 54. & Myrinus & - & $151-300$ & CIL III $, 14213,3$ \\
\hline 55. & Valerius Diogas & - & \multirow{2}{*}{$51-200$} & \multirow{2}{*}{ CIL III, 14434} \\
\hline 56. & Marina Demetria & & & \\
\hline 57. & $\mathrm{M}$ (arcus) $\mathrm{Ve}(\ldots)$ & militar (centurion) & \multirow{2}{*}{$101-300$} & \multirow{2}{*}{ CIL III, 14435} \\
\hline 58. & $\mathrm{G}($ aius $) \mathrm{Go}(\ldots)$ & fiul? precedentului & & \\
\hline 59. & Antonius Marcianus & - & \multirow{3}{*}{$151-250$} & \multirow{3}{*}{ Donevski 1976, nr. 5} \\
\hline 60. & (Marcus?) Timotheus & - & & \\
\hline 61. & $C$ (aius) Antonius Olympus & - & & \\
\hline 62. & Onesimus? & $=$ & \multirow{2}{*}{$101-300$} & \multirow{2}{*}{ Kalinka 1906, 426} \\
\hline 63. & Prima & - & & \\
\hline 64. & Iulius Iulianus & veteran (LEG XI CLAUDIA) & \multirow{2}{*}{$151-170$} & \multirow{2}{*}{ Petolescu 2004, 239} \\
\hline 65. & Valeria Crispina & soția precedentului & & \\
\hline 66. & Q(uintus) Samicius Serenus & arhitect & $171-230$ & Russu 1933-1935, nr. 3 \\
\hline 67. & Valentius & militar (LEG XI CLAUDIA) & \multirow{2}{*}{$271-330$} & \multirow{2}{*}{ Russu 1933-1935, nr. 4} \\
\hline 68. & Alexandra & soția precedentului & & \\
\hline 69. & $\begin{array}{l}\text { Aurelius Codratus } \\
\text { (Quadratus?) }\end{array}$ & - & $171-300$ & Russu 1933-1935, nr. 2 \\
\hline
\end{tabular}




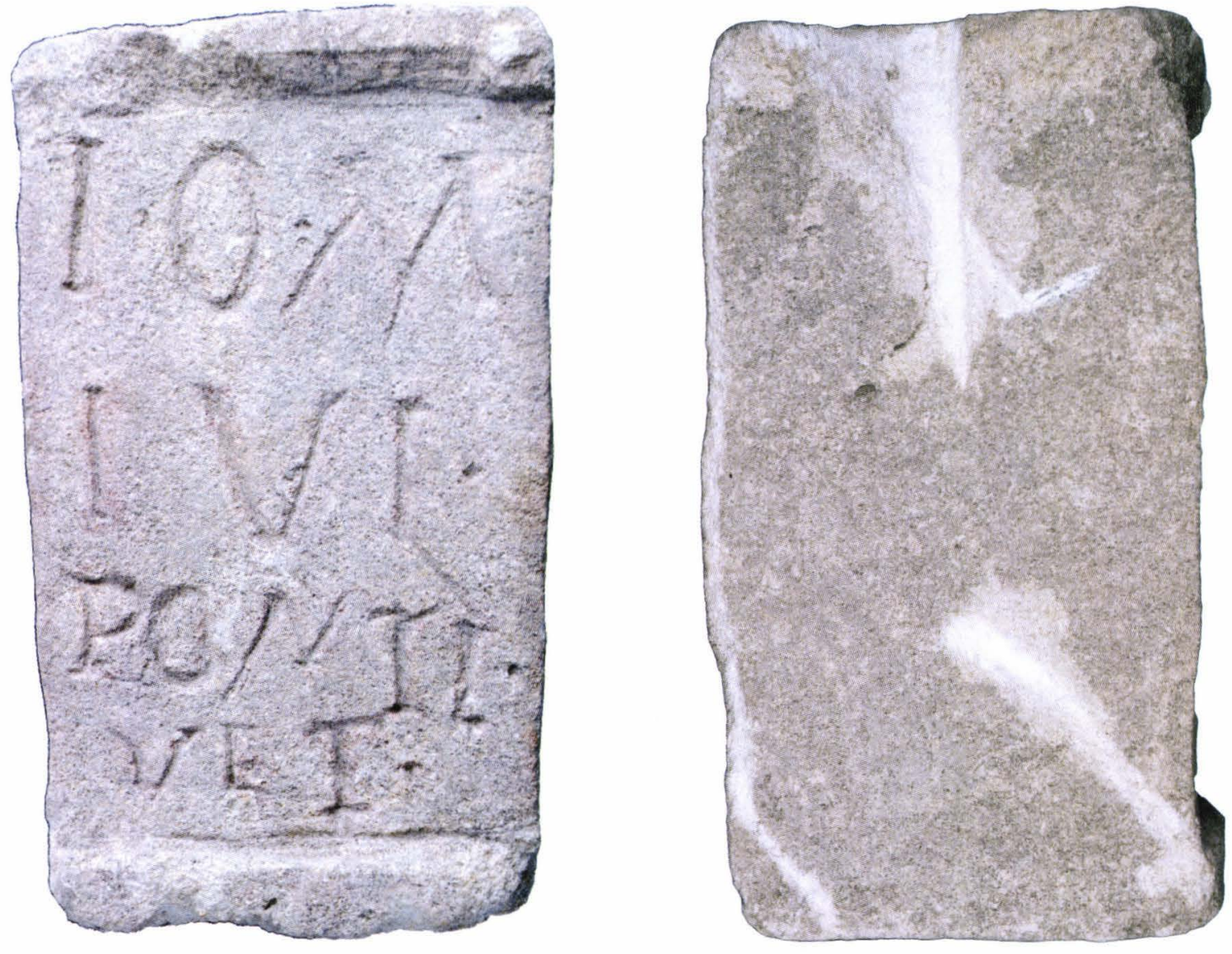

1.
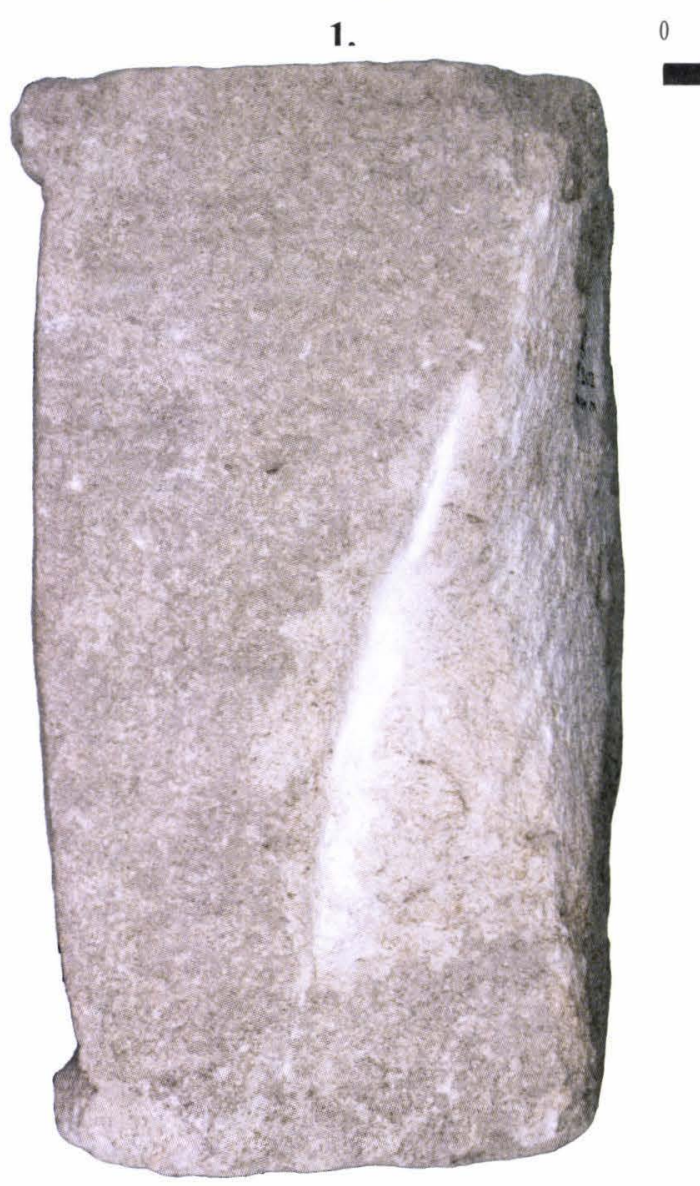

2.

3.

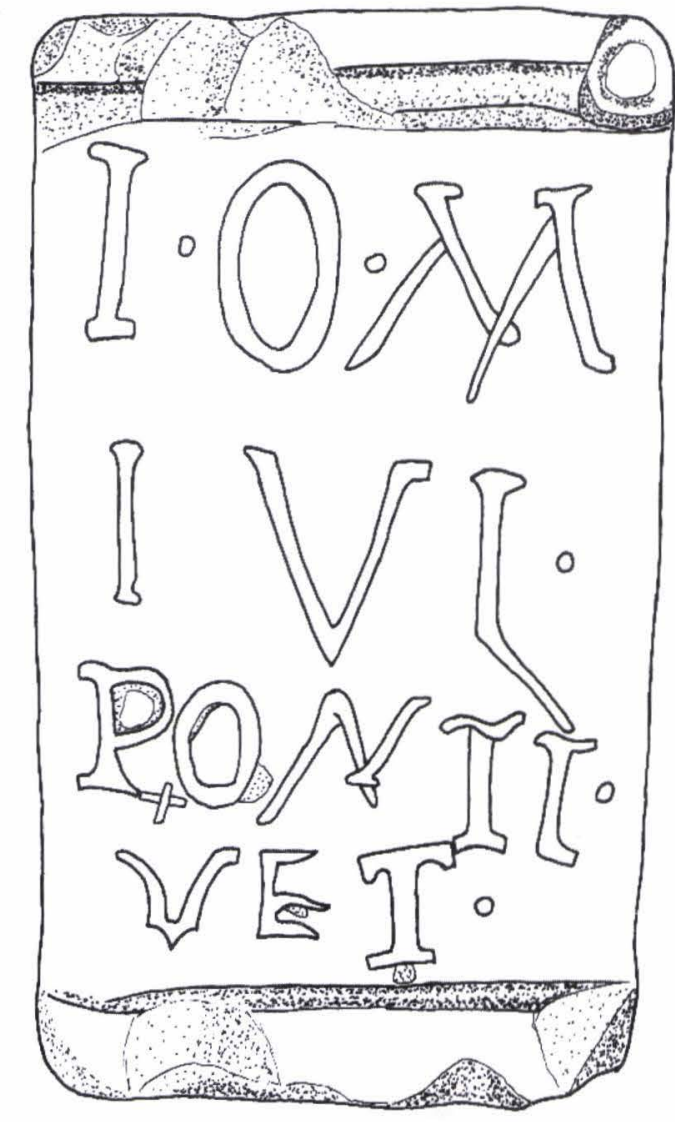

4.

Altar votiv miniatural de la Ostrov (Punctul Ferma 4, jud. Constanța)

PI. I 
